\title{
ANTIOXIDANT STATUS IN EFFLUENT TREATED GRAINS OF Vigna radiata
}

\author{
P. Baby Shakila MPhil ${ }^{* 1}$ and K. Usha PhD ${ }^{2}$
}

\begin{abstract}
Effect of tannery effluent on the growth and anti oxidant status of Vigna radiata (L.) $R$. Wilcz. was investigated in 2009. Plants were grown in two dilutions and the results were compared with the control plants grown simultaneously in the same condition. Enzymic and non-enzymic antioxidants were analyzed in the grains. The antioxidant enzyme superoxide dismutase was found increased when the concentration of the effluent increased. Where, the concentration of catalase, peroixidase, glutathione system, polyphenol oxidase, ascorbic acid, tocopherol, polyphenol, lycopene and carotenoid were decreased when the concentration of the effluent increased. This study proves that Vigna radiata should not be grown in the soil having highest level of tannery effluent for maintaining human health and the environment.
\end{abstract}

Keywords: antioxidant, tannery effluent, Vigna radiata

\section{INTRODUCTION}

Plants have played a crucial role in maintaining human health and improving the quality of human life for thousands of years. The World Health Organization has estimated that world's $80 \%$ of inhabitants relied on traditional medicine for their primary health care needs and most of this therapy involved the use of plant extracts as their active components. They were believed to possess hypolipidemic, antitumor or immune stimulating properties that may be useful adjuncts in helping to reduce the risk of cardiovascular disease and cancer (Palasuwan et al., 2005). The exposure of plants to various stimuli results in the overproduction of active oxygen species such as superoxide, hydrogen peroxide and hydroxyl radicals. Plants are equipped with complex antioxidants systems composed of low molecular mass antioxidants and enzymes that protect cellular membranes and organelles from damaging effects of reactive oxygen species (ROS). The antioxidant enzymes and free radical scavengers may provide a defensive mechanism against the deleterious actions of ROS. Some of the antioxidant enzymes that are found to provide protection against the ROS are superoxide dismutase, catalase, peroxidase, glutalthione peroxidase, and ascorbate oxidase (Rani et al., 2004). Free radicals are implicated in several degenerative diseases such as arteriosclerosis, diabetes, arthritis, cancer and aging. The harmful effects of free radicals on living systems could be attenuated by antioxidants that scavenge the free radicals. Plants are rich sources of natural antioxidants, which play a vital role in the prevention or progression of the degenerative diseases. The consumption of fruits, vegetables and herbs rich in antioxidants is associated with a decline in the incidence of degenerative diseases and cancer (Harish et al., 2005).

Industrial disposal is a major waste of ecological concern. The solid as well as effluent wastes are highly polluted and pose serious health hazard to the population in nearby areas. The waste water causes soil and ground water pollution besides causing a number of adverse effects on animals and health of people living in that area since it contains waste chemicals and toxic metals. Thus it has been considered world wide to investigate the status of pollutants in the effluents, water and amended soils in these areas (Kulkarni and Shrivastava, 2000). Metal toxicity to man is an increasingly important environmental concern. The primary cause of toxicity of the different metal ions may be as different as

\footnotetext{
${ }^{1}$ Rev Jacob Mem. Christian Col., Ambilikai, 624612. Email : babyshakila_06@yahoo.co.in

${ }^{2}$ Reader, Dept. of Biochemistry and Biotechnology, Avinashilingam University, Coimbatore
} 
their chemical properties especially valence, ion radius and capacity to form organic complexes. Nevertheless, excess of these metal ions or of soluble metal chelates may induce a series of biochemical and physiological alterations in plants such as membrane damage, alteration of enzyme activities, inhibition of root growth, deficiency of essential nutrients, inhibition of photosynthesis, changes in photoassimilate translocation and alteration of water relations which further enhance the metal-induced growth reduction (Rana and Aery, 2005). Antioxidants interfere with the production of free radicals and also a key role to inactivate them (Prakash et al., 2007). Antioxidants neutralize the effect of free radicals through different ways and may prevent the body from various diseases (Gupta and Sharma, 2006). The antioxidant properties of plants could be correlated with oxidative stress defense in different human diseases including cancer, atherosclerosis, Alzheimer's and the ageing processes (Malencic et al., 2000). Hence the impacts of deposition of pollutants from tannery effluent on the antioxidant levels of selected plant were analysed. The plant selected was Vigna radiata, locally called as Mung bean, mash bean, green gram, golden gram and green soy. It is native to India The beans are small, ovoid in shape and green in color. The mung bean is one of many species recently moved from the genus Phaseolus to Vigna and is still often seen cited as Phaseolus aureus or Phaseolus radiatus.

\section{OBJECTIVE}

The objective of the study was to investigate the level of enzymic and non-enzymic antioxidants in the grains of Vigna radiata grown on different soils containing different concentration of Tannery effluent.

\section{METHODOLOGY}

The seeds of the Vigna radiata (BG Co 5) selected for the study was collected from Tamil Nadu Agricultural University in Coimbatore. The seeds of the Vigna radiata were sown in the red soil packets and grown under two different concentrations of the tannery effluent (25\%, $50 \%$ concentrated effluent). Control plants (without the addition of effluent) were also grown along with the experimental plants. When $75 \%$ and $100 \%$ concentrated effluent was tried there was no characteristics growth of the plant. So for further study $25 \%$ and $50 \%$ concentrated effluent were taken. The plant was grown for more than 90 days and the seeds were collected. Enzymic and non enzymic antioxidants were estimated in the seed samples of control and test plants. Antioxidants analyzed and the methods of analysis are listed in table1.

\section{RESULTS AND DISCUSSIONS}

\section{ENZYMIC ANTIOXIDANTS IN GRAINS OF CONTROL AND EFFLUENT TREATED PLANTS}

Catalase activity was maximum in grains of control plants than the grains of plants grown in $25 \%$ diluted and $50 \%$ diluted effluent (Table 2 ). The same trend was observed in peroxidase levels also. A significant decrease in peroxidase levels of grains of treated with effluent was observed than the grains of control plants. A different trend was observed in the activities of superoxide dismutase. Super oxide dismutase seems to have been released due to the stress of heavy metals accumulated in the soils. The plants grown in $50 \%$ diluted effluent were exposed to a higher concentration of heavy metals than the plants grown in $25 \%$ diluted effluent which obviously received a lesser concentration of pollutants than plants of $50 \%$ effluent and higher than the control plants. Amount of polyphenol oxidase was higher in seeds of control plants $(0.942 \mathrm{u} / \mathrm{g})$ than the seeds of effluent treated plants $(0.905 \mathrm{u} / \mathrm{g}$ and $0.879 \mathrm{u} / \mathrm{g}$ ). Studies have revealed that orange, tomato and grapes possess predominant quantities of enzymatic antioxidants namely SOD, catalase and glutathione peroxidase respectively. (Rani et al., 2004). Endogenous antioxidant enzymes (SOD and catalase) are responsible for preventing and neutralizing the free radical induced damages on tissues. 
Studies have shown that in Spirulina enzymes SOD and catalase constitute the first line of defence against free radical induced damage (Jayaprakash and Chinnaswamy, 2007).

Table 1: Parameters analysed and method of analysis

\begin{tabular}{lll}
\hline S.N. & \multicolumn{1}{c}{ Antioxidants } & Method of analysis \\
\hline & Enzymic antioxidants & \\
1 & Catalase (CAT) & Luck (1974) \\
2 & Peroxidase & Reddy et al., (1995) \\
3 & Superoxide Dismutase (SOD) & Misra and Fridovich (1972) \\
4 & Polyphenol oxidase & Esterbauer et al.,(1977) \\
5 & Glutathione- S- transferase (GST) & Habig et al., (1974) \\
6 & Glutathione peroxidase (GSH - Px) & Rotruck et al.,(1973) \\
7 & Glutathione reductase (GR) & David and Richard (1983) \\
& Non enzymic antioxidants & \\
8 & Ascorbic acid & Roe and Keuther (1953 \\
9 & a- Tocopherol & Rosenberg (1992). \\
10 & Reduced glutathione & Moron et al., (1979) \\
11 & Polyphenol & Malick and Singh (1980) \\
12 & Carotenoids & Zakaria et al., (1979) \\
13 & Lycopene & Zakaria et al., (1979) \\
\hline
\end{tabular}

Table 2: Enzymic antioxidants (Units/g)

\begin{tabular}{lllll}
\hline & Catalase & Peroxidase & Superoxide dismutase & Polyphenol oxidase \\
\hline Control & 524.33 & 1.553 & 5423.33 & 0.942 \\
$25 \%$ & 518.6 & 1.363 & 5441.23 & 0.905 \\
$50 \%$ & 502.5 & 1.235 & 5601.7 & 0.879 \\
\hline
\end{tabular}

The values are mean of triplicates.

Enzymes Units :

Catalase: Amount of enzyme required to decrease the optical density by 0.05 units

Peroxidase: $1 \mu$ mole of pyrogallol oxidized/minute

Superoxide dismutase: Amount that causes 50\%reduction in the extent of NBT oxidation Polyphenol oxidase: Amount of enzyme that transforms $1 \mu$ mole of dihydrophenol to 1 mole of quinine/min

\section{ENZYMIC ANTIOXIDANTS IN GRAINS PRODUCED FROM EFFLUENT TREATED PLANTS}

Glutathione is a cysteine containing peptide found in high concentration and functions in maintain the cell's redox state in the plants. The glutathione system includes glutathione, glutathione peroxidase, glutathione reductase and glutathione $s$ transferases (Meister and Anderson, 1983) all the three enzymes of glutathione system were found decreased as the concentration of the effluent increased. Grains from plants grown in $25 \%$ and $50 \%$ concentrated effluent had a lesser enzymic levels than the controls grains (Table 3 ).

Estimated non-enzymic antioxidants reduced glutathione, total phenol, ascorbic acid, and tocopherol in the grains of the selected plant showed a progressive decrease as the concentration of effluent increased (Table 4). Grains of $50 \%$ effluent had a least amount of the antioxidants compared to the grains from $25 \%$ effluent treated plants and control ones. 
Vitamin $\mathrm{E}$ and Vitamin $\mathrm{C}$ are potent free radical scavengers and prevent oxidative damage by utilizing the free radicals. Among the non enzymic antioxidants studied reduced glutathione in grapes, Vitamin $\mathrm{C}$ in orange and vitamin $\mathrm{E}$ in tomato were predominant antioxidants (Rani et al., 2004).Vitamin C has antioxidant activity when it reduces oxidizing substances such as hydrogen peroxide (Duarte and Lunec, 2005). It can also reduce metal ions, which lead to the generation of free radicals through the fenton reaction (Carr and Frei, 1999). This appears to have mostly antioxidant action in the body (Valko et al., 2005). In cells vitamin $C$ is maintained in it's reduced from by reaction with glutathione, which can be catalyzed by protein disulphide isomerase and glutaredoxins. Ascorbic acid is a reducing agent that can reduce and thereby neutralize oxygen species such as hydrogen peroxide (Padayatty et al., 2003). The effluents with high organic matters are biodegradable and are usually accompanied by very high biochemical oxygen demand values, causing environmental pollution (Trivedi, 2004). Heavy metals are kept under environmental pollutant category due to their toxic effects on plant animals and human (Sharma and Agrawal, 2005). Hexavalent chromium is one of the dominant oxidation states of chromium that exist in the environment and is highly toxic to all forms of life (Mary et al., 2008).

Table 3: Enzymic antioxidants (u/g)

\begin{tabular}{cccc}
\hline & $\begin{array}{c}\text { Glutathione S } \\
\text { transferase }\end{array}$ & $\begin{array}{c}\text { Glutathione } \\
\text { reductase }\end{array}$ & Glutathione peroxidase \\
\hline control & 0.0467 & 1.046 & 783.6 \\
$25 \%$ & 0.0394 & 1.037 & 758.9 \\
$50 \%$ & 0.0299 & 1.021 & 728.4 \\
\hline
\end{tabular}

The values are mean of triplicates

Table 4: Non enzymic antioxidants, reduced glutathione, total phenol, ascorbic acid and a tocopherol

\begin{tabular}{lcccc}
\hline & $\begin{array}{c}\text { Reduced } \\
\text { glutathione }(\mathrm{u} / \mathrm{g})\end{array}$ & $\begin{array}{c}\text { Total phenol } \\
(\mathrm{u} / \mathrm{g})\end{array}$ & Ascorbic acid & $\begin{array}{c}\text { a tocopherol } \\
(\mathrm{u} / \mathrm{g})\end{array}$ \\
\hline control & 0.413 & 0.853 & 0.254 & 0.254 \\
$25 \%$ & 0.389 & 0.819 & 0.216 & 0.216 \\
$50 \%$ & 0.352 & 0.775 & 0.189 & 0.189 \\
\hline
\end{tabular}

\section{CONCLUSIONS}

Tannery effluent used in high concentration spoils the crop plants growth and affects the enzymic and non-enzymic antioxidants in the edible part. But a less concentrated effluent along with water could be used for irrigation purpose to produce Vigna radiata.

\section{REFERENCES}

Carr, A and B. Frei, 1999. Does vit.C act as pro oxidant under physiological conditions. FASEB J., 13(9): 1007-24

David, M. and J. S. Richard, 1983. Methods of enzymatic analysis. In: J. Bergmeyer and G. B. Marianna (eds.), Verlag Chemie Wein Hein Dein Field, Beah Florida, Basel, 26:358-9.

Duarte, T. L and J. Lunec, 2005. Review: when is an antioxidant not an antioxidant, a review of novel actions and reactions of vitamin C. Free Radic. Res., 39(7): 671 - 86

Esterbauer, H., E. Schwartz and M. Hayan, 1977. A rapid assay for atechol oxidase and laccase using 2nitro-5-thiobenzoicacid. Anl. Bio. Chem., 7:489-494. 
Habig, W. H., M. J and W. B. Pabstand Jacoby, 1974. Glutathione-S-transferase: the first enzymatic step in mercapturicacid formation, J. Biol. Chem., 249: 7310 - 7339.

Jeyaprakash, $\mathrm{K}$ and $\mathrm{P}$. Chinnaswamy, 2007. Antioxidant property of Spirulina and Liv-52 against lead induced toxicity in albino rats. J. Nat. Remedies, 7(1): $80-85$

Malick, C. P. and M. B. Singh, 1980. In: Plant enzymology and histo enzymology, Kalyani publishers, New Delhi (India), 286.

Mary, M. S., J. B. V. R. Gapal, J. S. Tata, S. Rao and S, Viveat, 2008. A confocal microscopic study on colocy morphology and sporulation of bacillus sp world. Microbiol Biotechnol, 24: 2435 - 2442

Meister, A. and M. Anderson, 1983. Glutathione. Annu. Rev. Biochem., 52: 711-60.

Moron, M. S., J. N De Pierre and V. Manervik, 1979. Levels of glutathione, glutathione reductase and glutathione -S- transferase activities in rat lung and liver. Bio. Chem. Biophys. Acta., 582: 67-68.

Misra, M. P. and I. Fridovich, 1972. The role of supreoxide anion in the auto oxidation of epinephrine and simple assay for super oxide dismutase. J.Biol.Chem., 247: 31-70.

Padayatty, S., A. Katz, Y.Wang, P. Eck, O. Kwon, J. Lee, S. Chen, C. Corpec, A. Dutta, S. Dutta, and M. Levine, 2003. Vit $C$ as an antioxidant: evaluation of its role in diease prevention. J. Am. Coll. Nutr., 22(1): 18-35

Rani., P., U. K. Meena and J. Karthikeyan, 2004. Evaluation of antioxidant properties of berries. Ind. J. of Clini. Biochem., 19(2):-103-110.

Reddy, K. P., S. M. Subhani, P. A Khan and K. B. Kumar, 1995. Effect of light and benzyl adenine on dark-treated growing rice leaves, II changes in peroxidase activity. Plant cell physiol., 24:987-994.

Roe, J. H and, C. A. Keuther, 1953. The determination of ascorbic acid in whole blood and urine through 2,4-dinitrohenyl hydrazine derivatives of dehydroascorbic acid. J. Biol. Chem., 147:399-407.

Rosenberg, H. R., 1992. Chemistry and Physiology of the Vitamins. Inter Science Publisher Inc.

Rotruck, T. T. A. L., H. E. Ganther, A. B. Swamson, D. G. Hafeman, and W. G. Hoeckstra, 1973. Selenium: biochemical role as a component of glutathione peroxidase. Science, 179:588-590.

Sharma, R. K and M. Agarwal, 2005. Biological effects of heavy metals: an overview. Journal of Environmental Biology, 26(2):301-313.

Trivedi, T., 2004. Water quality assessment of river, Thamirabharani at Ambasamudram. J. Ecotoxical. Environ. Monit, 14(4):273 - 276.

Valko, M., H. Morris and M. T. Cronin, 2005. Metals toxicity and oxidative stress. Curr. Med. Chem., 12(10):1161 - 208

Zakaria, H., K. Simpson, P. R. Brown and A. Krotulovic, 1979. Use of reversed phase HPLC analysis for the determination of provitamin A, carotenes in tomatoes. J. Chromatography, 176:109-117. 